http://dx.doi.org/10.1590/0370-44672018730058

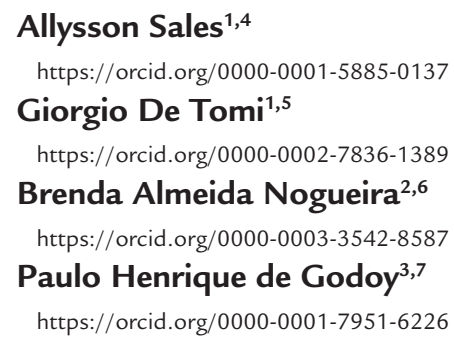

https://orcid.org/0000-0002-7836-1389

Brenda Almeida Nogueira ${ }^{2,6}$

https://orcid.org/0000-0003-3542-8587

Paulo Henrique de Godoy ${ }^{3,7}$

https://orcid.org/0000-0001-7951-6226

'Universidade de São Paulo - USP, Escola Politécnica Departamento de Engenharia de Minas e Petróleo,

São Paulo - São Paulo - Brasil.

${ }^{2}$ Universidade Federal do Sul e Sudeste do Pará, Instituto de Geociências e Engenharia,

Marabá - Pará - Brasil.

${ }^{3}$ Universidade Federal de Pernambuco - UFPE, Departamento de Engenharia de Minas,

Recife - Pernambuco - Brasil

E-mails: ${ }^{4}$ allysson.sales@vale.com,

5gdetomi@usp.br, giorgio.de.tomi@gmail.com,

6brendanogueira.eng@gmail.com, ${ }^{7}$ phgodoy@gmail.com

\section{Increased power efficiency in mining by ușing high-fidelity haul truck simulation}

\begin{abstract}
The current economic and political scenario in Brazil has allowed small, medium and large companies to adopt cost cutdown and productivity increase strategies. Diesel fuel consumption by off-highway haul trucks stands for one of the largest costs at the Sossego Mine operational management department. Based on this fact, as well as on the $8 \%$ increase in the budgeted diesel fuel cost for 2017, the mining unit has decided to implement a project, previously implemented at the Capão Xavier mine site, which makes use of a high-fidelity haul truck simulator for operators' qualification, by working on the major factors impacting fuel consumption. The application of the simulator has been observed to be a potential upturn for the identification and correction of major failures and bad habits impacting fuel consumption. The results suggest a significant diesel fuel consumption cutdown, as well as enhanced haul truck operation ability and performance.
\end{abstract}

keywords: diesel fuel, consumption, cost, simulator, haul trucks. 


\section{Introduction}

In the mining industry, cost control during the haulage phase, as well as throughout the production chain, has become quite relevant in a time of low market value of commodities worldwide. One of the consequences of this uncertainty scenario is a downsized demand, which forces mineral resource companies to optimize costs and increase their operational efficiency (Teixeira, 2016).

In high-production mine sites, where common material handling practice is carried out by large-size haul trucks, also known as off-highway trucks, one of the major issues encountered is high fuel consumption, due to a high value of Average Haulage Distance (AHD) for the work cycle haulage, from the mine site to the crusher, deposit or stockpiles (LOPES, 2010).

With that, requirements such as profit maximization, operational cost cutdown, and better mining throughput oblige mining companies to be always on the outlook for new alternatives to be able to meet proposed results and targets. Therefore, technology incorporation into the mining industry has become essential for attaining

\section{Methodology}

The study has been divided into two stages. The first stage, Pilot Project, aimed at ascertaining the methodology, with a smaller sample of operators. The second stage, Extended Project, consisted of the application of pilot project techniques to all operators.

A Pilot Project was carried out in two phases: 1) Simulator: operators' training and qualification, focused on major failures impacting fuel consumption; 2) Hands-on Practice: monitoring of operators' haul truck consumption performance for validation of simulation results.

For the training sessions, eight operators were selected, two from each one of the four mine groups, of the two haul trucks with the highest average specific fuel consumption (liters/hour) in 2017. By using such criterion, some of the operators with the highest diesel fuel consumption per equipment could be selected.

The four-hour simulation training consisted of driving on a preset route, common for all operators, divided in five stages: 1) Familiarization: five-minute stage to make operator familiar with the training equipment (simulator); 2) Initial Assessment: operator drove freely on the preset cost reduction and high productivity rates (Dias, 2017).

Technology development has brought about a new integration and sophistication aspect to evolving maintenance of both processes and real-world issues. In such scenario, virtual reality (Riener et al., 2004) plays a major role, for it stands for advanced computer interfaces, which have not yet been fully implemented by society at large.

The latest evolution for advanced training solutions are high-fidelity simulators for the mining industry. Such simulators offer an array of visual effects, consisting of high-definition screens and an advanced movement system, with simulation connected to a learning management system, in order to follow up on the progress of the driver in training. Simulation scenarios reproduce climate and dynamic conditions of the ore exploration location, so that professionals may be trained exactly as they were on an actual mine site (VALE, 2017).

Operator training based on this new learning system using simulation, has been successfully applied in the mining industry, where high risk and cost are everyday issues demanding immediate and effective solutions. According to Immersive Technologies (2013), the use of advanced simulation adds significant enhancement to the production environment.

The present study aimed at developing an in-depth study of simulation technology application as a supporting system for operator qualification, as well as a study instrument for haul truck fuel consumption cutdown at the Vale Sossego mine site.

The operating Sossego copper mine unit is located in the municipality of Canaã dos Carajás, state of Pará, Brazil. The copper deposit was discovered in 1997 and operational startup took place in 2004 (Costa and Scoble, 2006). The project derives from a wide and successful mineral exploration program for base metals started out by Vale. It is considered an important milestone in copper mining history in Brazil, for it has opened up a path for the discovery, characterization and development of several medium to large-size copper ore deposits (Brazilian Mines and Energy Ministery, 2009).

route, without any guidance or interference by the instructor; 3) Feedback: instructor assesses the data reported by the simulator and guides the operator about which actions to take; 4) Practices: three practical procedures performed with full instructor guidance, aiming at developing operator's abilities to cut down on fuel consumption; 5) Final Assessment: similarly to the initial assessment, operator drove again on the same preset route, without guidance by the instructor, aiming at comparison with initial assessment data. At the end, instructor collected and assessed the training data.

Based on the mandatory variable, specific diesel fuel consumption (L/h), if the operator got a result on final assessment higher than the one recorded in the initial assessment, he/she would go through the training sessions again, otherwise the operator would go to the analysis of the second variable, average speed $(\mathrm{L} / \mathrm{h})$. For this one, the adopted rule was that the operator could not have a result below the overall average, calculated from the data of all trained operators.

Upon finishing the simulation training, the eight operators were taken to the haul truck for hands-on practice on site.
For comparison purposes, eight other operators and a second haul truck were selected according to the same selection criteria described above. Over 15 days, the two haul trucks were always driven on the same preset routes, so that the influence of distance and haulage profile over diesel fuel consumption might be minimized. During this stage, all persons involved (operators, supervisors, operation and dispatch technicians, engineers, and mechanics) were made sure to be on the same page regarding the assumptions for a successful test. Fuel consumption was monitored on a daily basis with data from the weighed filling station.

The Extended Project consisted of applying the pilot project to all operators. Training sessions were performed with two operators a day, due to the 4-hour training working load. This stage encompassed planning, schedule development, and training of 162 Sossego Mine haul truck operators, taking into account working, off-duty and vacation hours. The 4-month long stage followed the same procedure adopted for pilot training.

Fifteen days after simulation training, the operators went through a new on-site 
assessment by the instructor. Through a checklist, as shown on Figure 1, with major failures impacting fuel consumption, the instructor then assessed the operation. The factors of greatest impact are those related to excessive motor rotation, represented with greater weight in the assessment by instructor. The minimum score for approval is 8 points, with operator having to undergo new simulation training sessions should he/she be scored below that.

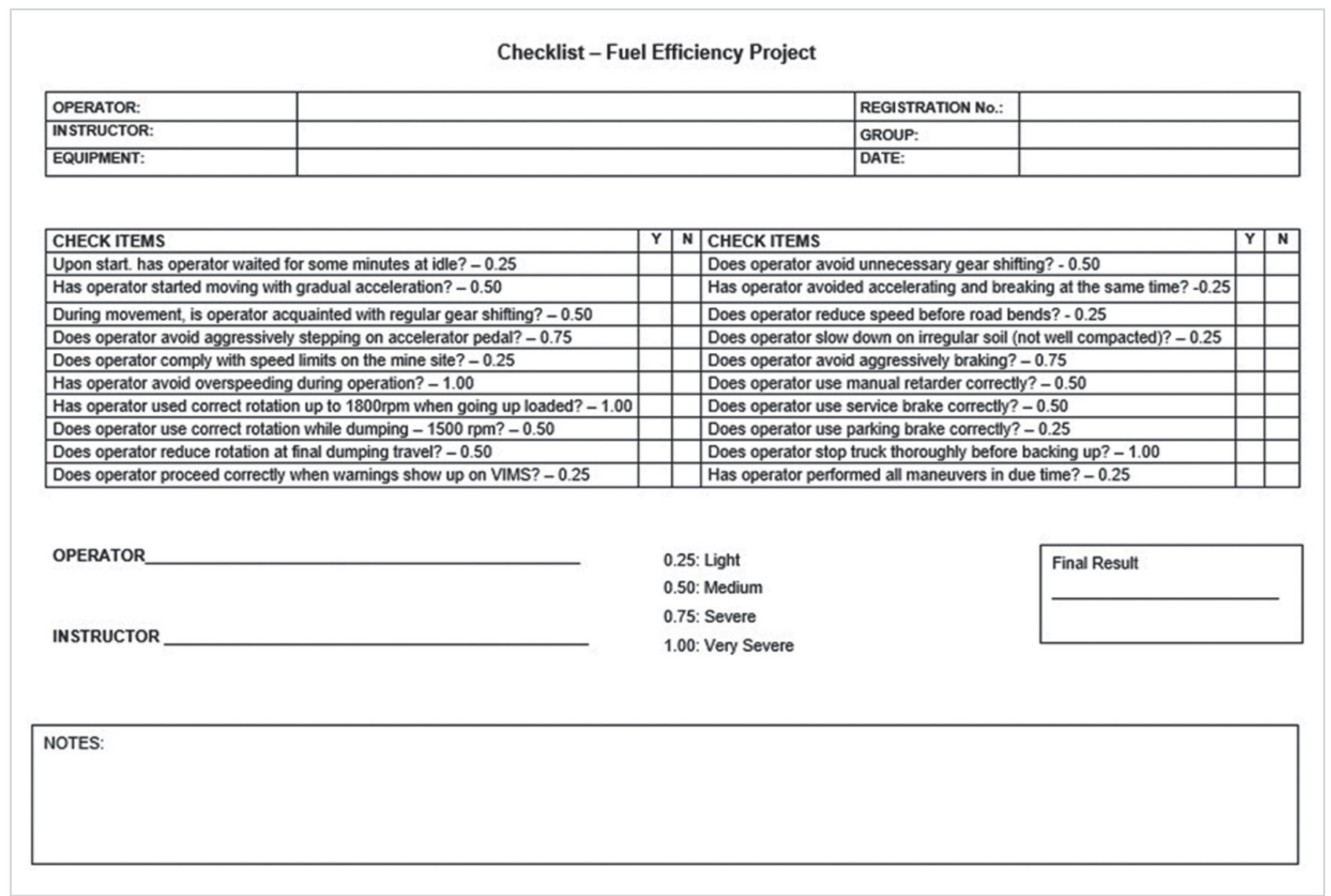

Figure 1 - Operational diagnosis checklist.

As it is the case with the pilot project, during extended project fuel consumption data are monitored on a monthly basis

based on weighed filling station data.

\section{Results}

\subsection{Pilot project}

Collected data were analyzed by the simulator software. Figure 2 shows the evolution of the final op- erator assessment regarding failures directly impacting fuel consumption. It is a remarkable reduction of overall error scoring from the initial assessment to the final assessment.

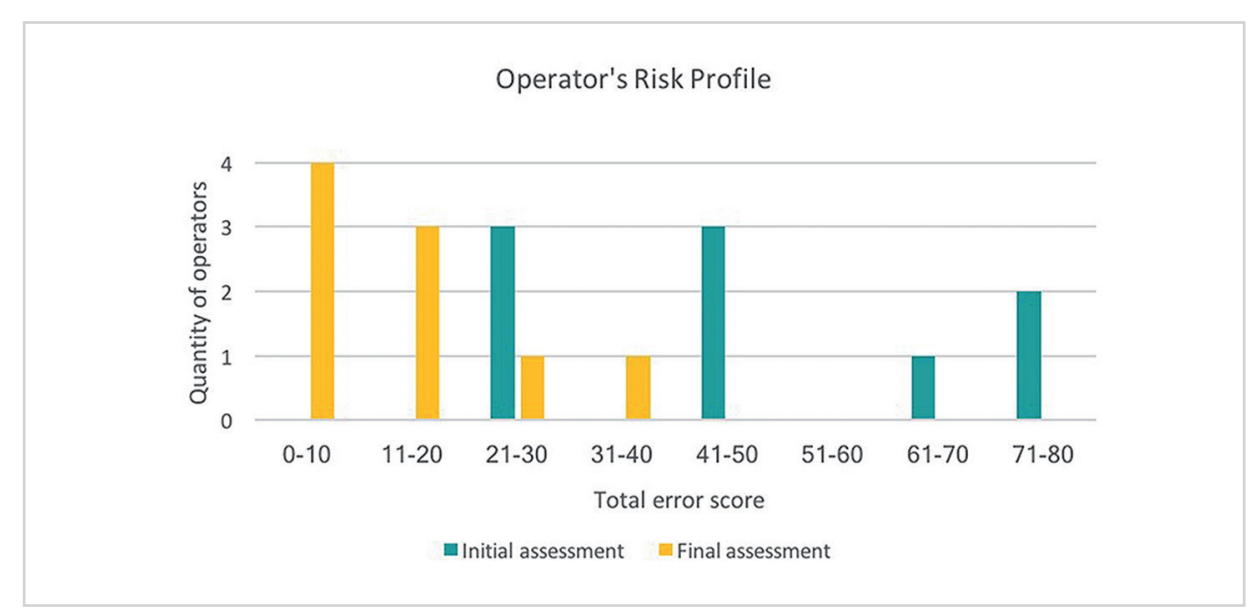

Figure 2 - Risk profile assessment. 
Figures 3 and 4 show total consumption data (liters) and specific consumption (liters/hour) of initial and final assessments. It can be noted that in the overall average there has been a total consumption cutdown of $6 \%$ and
$10 \%$, respectively, thus proving simulation training efficacy.

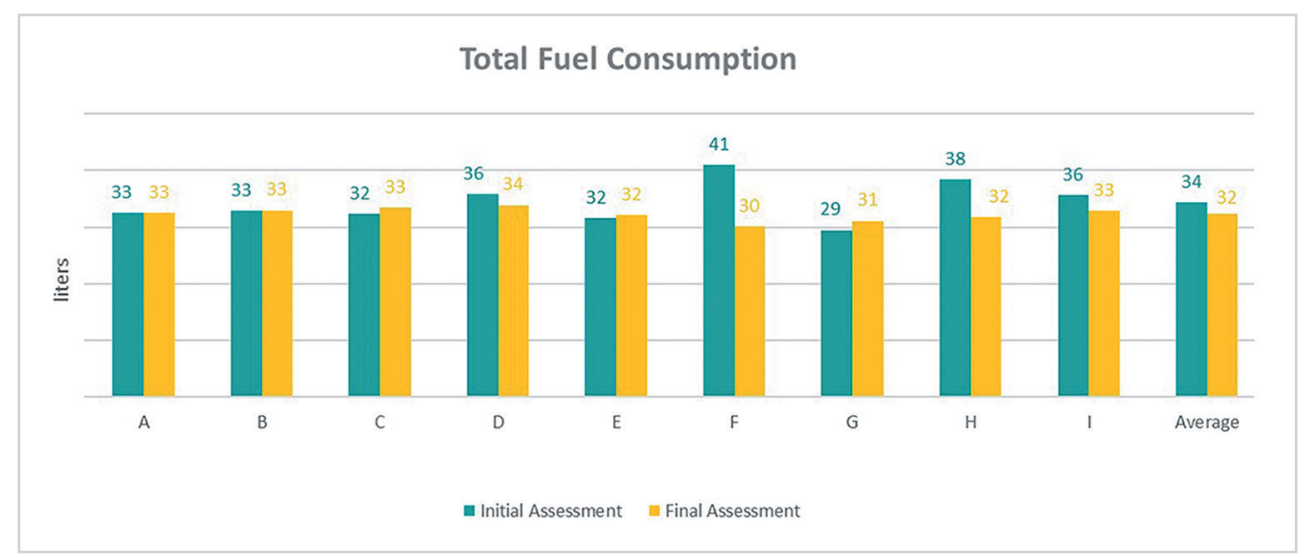

Figure 3 - Total consumption of initial qualification.

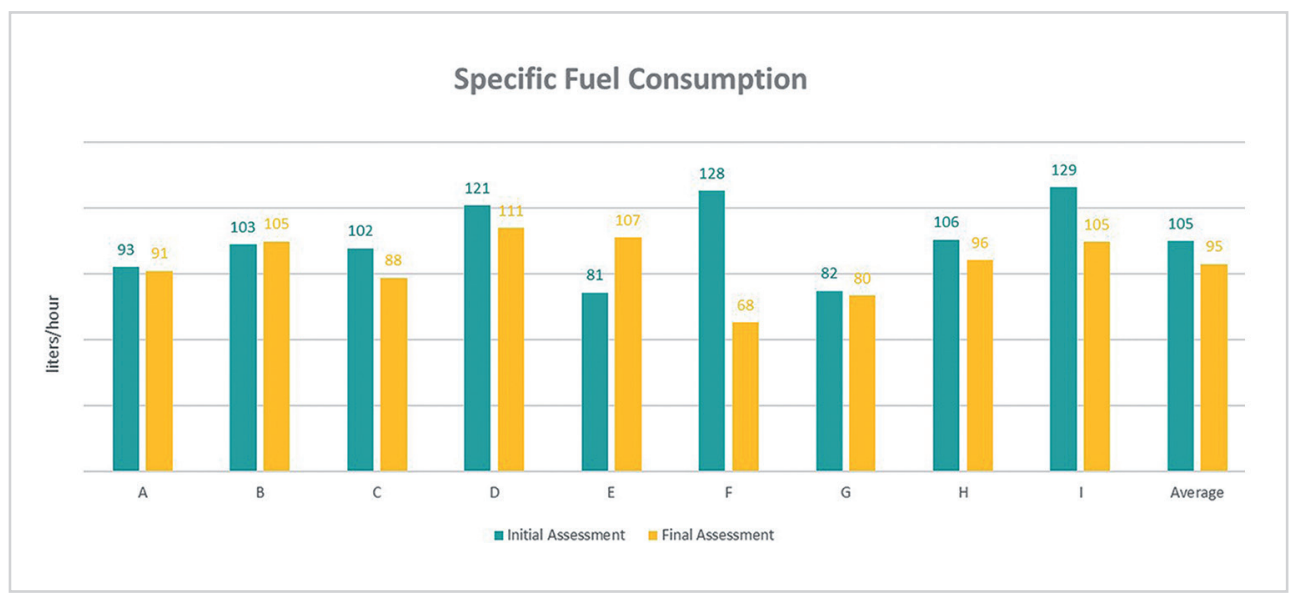

Figure 4 - Specific consumption of initial qualification.

Operators' improvement is noteworthy regarding errors made from initial to final assessment. Virtually all errors have been corrected, except for aggressive driving through bends and movement in neutral before brak- ing, which have had opposite results from what was expected, as shown on Figure 5 .

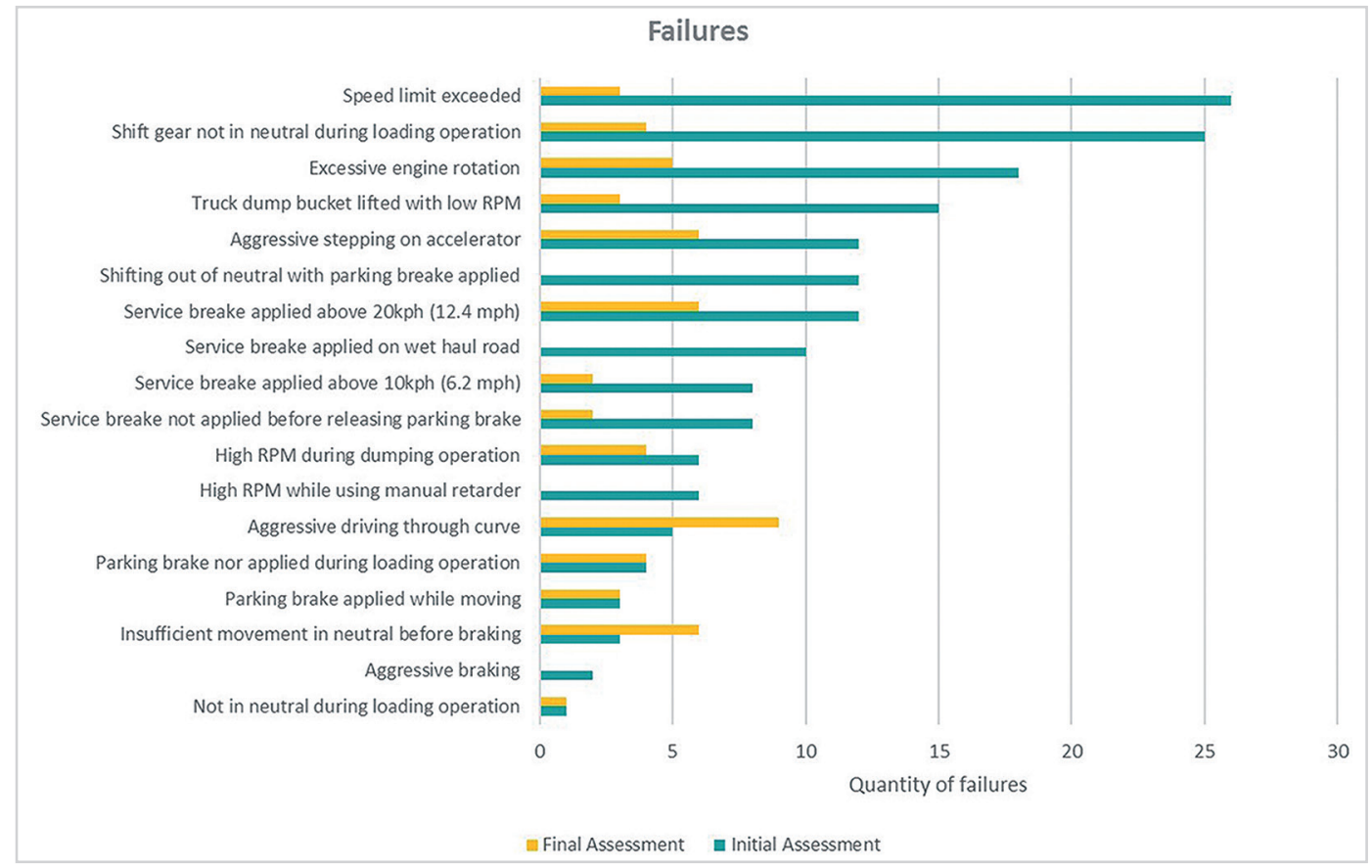

Figure 5 - Failures assessed. 
The final result achieved was a 7.5\% specific consumption cutdown for the truck driven by trained employees, when compared to the truck driven by untrained employees. In addition to a $7.2 \%$ cutdown in the same indicator, when compared to the average of the whole haul truck fleet, as shown on Figure 6.

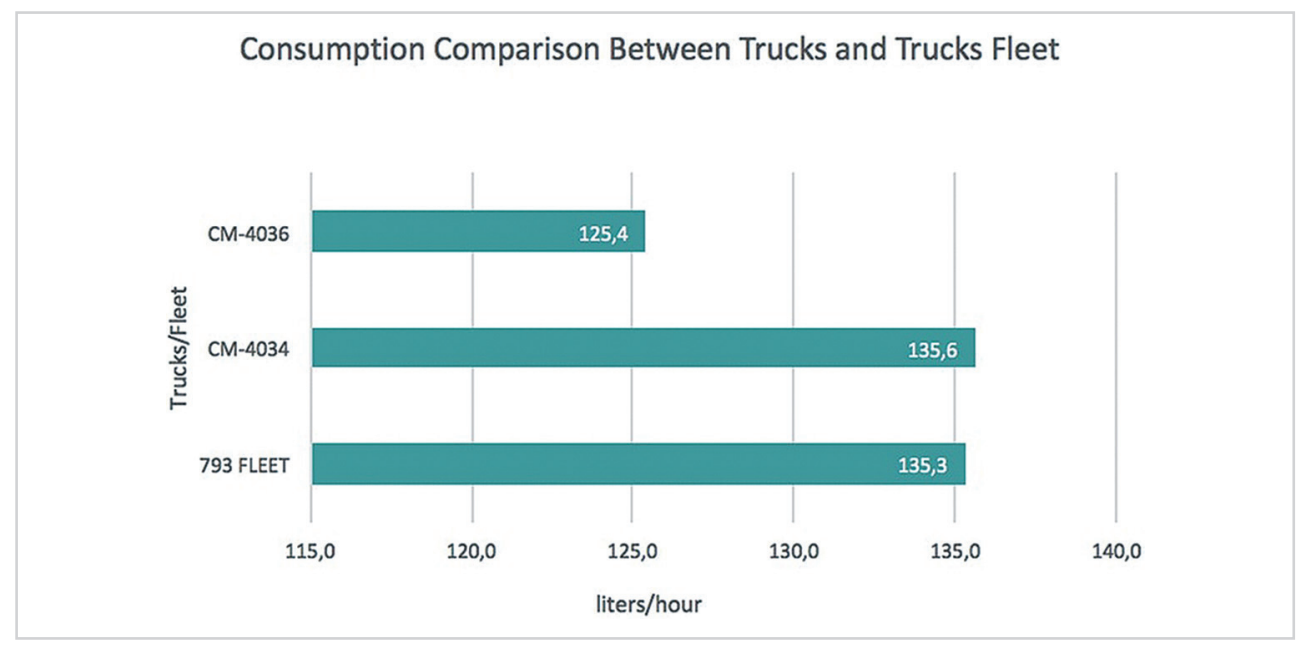

Figure 6 - Consumption comparison between trucks and trucks fleet.

\subsection{Extended project}

During this stage, 162 operators were trained on the simulator, with a $5.4 \%$ total fuel consumption cutdown, and $13.2 \%$ specific fuel consumption cutdown. Out of these 162 operators, 22 showed performance below the expected rates, having to undergo new simulation training sessions. The Figure 7 shows how this analysis was actually done.

\begin{tabular}{|c|c|c|c|c|c|c|c|c|c|c|}
\hline \multirow[t]{2}{*}{ NAME } & \multicolumn{2}{|c|}{$\begin{array}{l}\text { SPECIFIC CONSUMPTION } \\
(\mathrm{L} / \mathrm{h})\end{array}$} & \multirow{2}{*}{$\frac{(9)}{114}$} & \multicolumn{2}{|c|}{ SPEED $(\mathrm{km} / \mathrm{h})$} & \multirow{2}{*}{$\frac{(;)}{108}$} & \multicolumn{2}{|c|}{$\begin{array}{l}\text { TOTAL CONSUMPTION } \\
\text { (L) }\end{array}$} & \multirow{2}{*}{$\frac{\text { (:) }}{110}$} & \multirow{2}{*}{$\frac{\text { RESULTS }}{\text { Overall }}$} \\
\hline & Initial & Final & & Initial & Final & & Initial & Final & & \\
\hline Operator 1 & 138,69 & 93,49 & (i) & 23,37 & 17,56 & (2) & 33,35 & 31,32 & (2) & (). \\
\hline Operator 2 & 127,51 & 97,92 & (-); & 21,93 & 18,78 & (-); & 34,77 & 32,34 & (-); & (2) \\
\hline Operator 3 & 112,83 & 93,67 & (2) & 19,60 & 17,70 & (2) & 32,51 & 31,36 & (2): & (2) \\
\hline Operator 4 & 110,04 & 97,09 & (2) & 19,36 & 18,93 & (2): & 32,92 & 32,55 & (2) & (2) \\
\hline Operator 5 & 105,68 & 104,32 & (2) & 18,55 & 19,47 & (2) & 32,36 & 31,64 & (-): & (2) \\
\hline Operator 6 & 112,52 & 107,81 & (2) & 19,70 & 19,05 & (2) & 35,31 & 33,81 & (2) & (2): \\
\hline Operator 7 & 145,43 & 109,83 & (2) & 23,29 & 19,43 & (2) & 39,09 & 34,54 & (2) & (2) \\
\hline Operator 8 & 95,13 & 94,66 & (2) & 18,42 & 17,90 & (2) & 28,26 & 31,69 & (2) & (2) \\
\hline Operator 9 & 141,63 & 111,17 & (). & 23,14 & 18,34 & (2) & 34,10 & 33,72 & (2) & (2) \\
\hline Operator 10 & 138,52 & 111,38 & (2) & 23,22 & 19,78 & (2) & 33,71 & 33,11 & (2) & (2) \\
\hline Operator 11 & 115,47 & 102,26 & (-); & 20,55 & 19,41 & (-); & 31,66 & 31,79 & (2) & (2): \\
\hline Operator 12 & 115,88 & 103,19 & (2) & 19,89 & 19,21 & (2) & 34,16 & 31,88 & (2) & (2) \\
\hline Operator 13 & 117,06 & 100,13 & (2) & 17,92 & 18,67 & (2) & 34,28 & 31,14 & (2) & (2) \\
\hline Operator 14 & 155,03 & 111,24 & (2) & 23,68 & 20,68 & (2) & 35,26 & 32,79 & (2) & (2) \\
\hline Operator 15 & 131,13 & 101,44 & (2) & 21,42 & 17,77 & (2) & 34,84 & 32,62 & (2) & (2) \\
\hline Operator 16 & 147,95 & 110,41 & (2) & 23,86 & 20,18 & (2) & 35,35 & 32,55 & (2) & (2) \\
\hline Operator 17 & 109,05 & 120,82 & (2) & 17,25 & 20,18 & (-); & 36,38 & 34,57 & (2): & (2) \\
\hline Operator 18 & 165,78 & 102,96 & (2) & 24,84 & 18,44 & (2) & 35,91 & 32,73 & (2) & (2) \\
\hline Operator 19 & 109,90 & 97,97 & (2) & 20,10 & 19,36 & (2) & 32,98 & 32,36 & (2) & (2) \\
\hline Operator 20 & 126,20 & 97,80 & (-); & 23,39 & 18,28 & (2) & 31,51 & 32,24 & (2) & (2) \\
\hline
\end{tabular}

Figure 7 - Assessment spreadsheet of operators' performance on the simulator.

During the on-site monitoring stage with the checklist, four operators showed performance below the ex-

\section{Discussion}

According to Leite and Lot (2012), training is deemed as a key organizational development process tool, and companies have started considering human resource development as an extremely relevant factor for their growth.

The project has shown that simulation training enhances operators' practice, by working on major failures impacting fuel consumption. This happens because pected rates.

The final result of this stage was an average specific consumption cutdown

training enables human beings to become more productive, thus contributing to better achievement of organizational objectives (Volpe, 2009).

Some years ago, in the mining industry, one theoretical training was carried out, with an instructor conveying all information to operators in a classroom. Such methodology is relevant; however, in the mining company scenario, some of $4.6 \%$ for the two haul truck fleets, which stands for an estimated savings of US\$680,000 for 2018 . 
structions of safety, operation (including the actions of recycling) instructions and maintenance there are carried out at the time of hiring.

Thus, it is quite relevant for other mining companies to get to know this technique, which brings about expressive results regarding fuel consumption cutdown.

\section{Conclusions}

Even though this is only an estimation and other factors might contribute to cut down on fuel expenses, it has been duly proved that simulation does contribute for fuel consumption cutdown, besides providing the company with significant gains.

Allied to this, the project did not generate costs for the company, being used in the training of operators the labor of the mine instructors and the simulator resource already belonging to the current structure of the mine.
Operator training hours are predicted on frame sizing, not resulting in hours of stationary equipment.

In the mining industry, simulators are typically used for a short time, especially to make new operators familiar with equipment operation. Correcting failures impacting fuel consumption, by using an existing equipment item on the mine site, becomes a rather powerful tool.

This research has proven that simulation usage is efficient for training processes, with clear efficacy in correcting routine operator errors, which have a direct impact in fuel consumption, mainly by increasing operator knowledge of the equipment through the updating of concepts, techniques, behaviors and performance feedback.

In addition to this, it has shown that the correction of such failures brings about a significant diesel fuel cost cutdown, which stood for savings of approximately US\$680,000 in the Sossego mine budget for 2018 .

\section{References}

COSTA, S. D.; SCOBLE, M. J. Mine accommodation strategies - Case studies in developing countries. In: INTERNATIONAL MINE MANAGEMENT CONFERENCE, 1., 2006, Melbourne. Proceedings[...]. Melbourne: The Australasian Institute of Mining and Metallurgy, 2006. p. 17-23.

DIAS, F. D. Estudo de implantação do minerador de superfície vermeer TL 1255 na mina de bauxita de Juriti/PA. 2017. 58 f. Monografia (Graduação em Engenharia de Minas) - Escola de Minas, Universidade Federal de Ouro Preto, Ouro Preto, 2017.

HORBERRY, T. J.; BURGESS-LIMERICK, R.; STEINER, L. J. Human factors for the design, operation, and maintenance of mining equipment. New York: CRC Press, 2010.

LEITE, P. A. R.; LOTT, T. C. C. Treinamento e desenvolvimento organizacional, uma ferramenta nas empresas atuais. Revista Científica Semana Acadêmica, Fortaleza, v. 1, n. 42, 2013. p. 1-10.

LOPES, J. R. Viabilização técnica e econômica da lavra contínua de minério de ferro com o uso de sistema de britagem móvel "in pit" auto propelido. 2010. 105 f. Dissertação (Mestrado em Engenharia Mineral) - Escola de Minas, Universidade Federal de Ouro Preto, Ouro Preto, 2010.

BRASIL. Ministério de Minas e Energia. Relatório técnico 63: perfil do cobre. Brasília: Ministério de Minas e Energia, 2009. 79p. Available at: http://www.mme.gov.br/documents/1138775/1256652/P37_RT63_Perfil_do_Cobre. pdf/68976b6f-13e9-4f1a-adde-c435aacbb009. Accessed on: December 02, 2017.

RIENER, R. et al. Phantom-based multimodal interactions for medical education and training: the Munich Knee Joint Simulator. IEEE Transactions on Information technology in Biomedicine, v. 8, n. 2, 2004. p. 208-216.

IMMERSIVE TECHNOLOGIES. Manual: referência específica de máquina de Simcontrol. Austrália: Immersive Technologies, 2013. 173 p.

TEIXEIRA, L. A. C. Caracterização de Payloads via telemetria. 2016. 83 f. Dissertação (Mestrado em Engenharia) - Escola de Engenharia, Programa de Pós-Graduação em Engenharia de Minas, Metalúrgica e Materiais, Universidade Federal do Rio Grande do Sul, Porto Alegre, 2016.

VALE, S. A. Realidade virtual leva ganhos e inovação à mina de Brucutu. [S. 1.]: Vale, 2017. Available at: http:// www.vale.com/brasil/PT/aboutvale/news/Paginas/realidade-virtual-leva-ganhos-e-inovacao-a-mina-de-brucutu. aspx. Accessed on: November 23, 2017.

VOLPE, R. A. Importância do treinamento para o desenvolvimento do trabalho. In: PSICOLOGIA.PT: O Portal dos Psicólogos. Portugal, 2009.

Received: 26 April 2018 - Accepted: 7 August 2019. 